\title{
Embodiment as a Performatively Posthumanist Form of Material Authorship in The Lesser Bohemians by Eimear McBride
}

\author{
Katarzyna Ostalska \\ University of Łódź \\ katarzyna.ostalska@uni.lodz.pl
}

Received 5 September 2021; accepted 27 December 2021; published 29 December 2021.

\begin{abstract}
The article examines the second novel of Eimear McBride (2016) The Lesser Bohemians from a viewpoint of New Materialisms, with a special emphasis on Karen Barad's concept of "mattering" and the notion of performative matter. Apart from Barad, the article draws upon the works of N. Katherine Hayles, Donna Haraway and Rosi Braidotti, to suggest a posthumanist reading of McBride's novel. The article examines embodiment in The Lesser Bohemians as both material and performative, arguing that its matter "authors" the text and the female body. The idiom of The Lesser Bohemians goes under scrutiny to trace analogies with modern science, especially quantum physics, which links McBride's novel (2016) with Barad's research.
\end{abstract}

Keywords: new Irish fiction; Eimear McBride; Karen Barad; New Materialisms; mattering; embodiment

The Lesser Bohemians, the second novel of a critically appraised new voice of the Irish experimental fiction, Eimear McBride (2016), depicts material re-groupings of diverse embodiment types: from the flesh, embodiment in atoms, thousands of cells and thousands of other bodies (Deleuze and Guattari, 1987), through all the body, corporeal inscriptions and incorporations, to end up with the Oedipal body. At the outset, the article employs a new (materialist) approach, explained by Rosi Braidotti as an "emphasis on the unity of all matter [...] the selforganizing or 'smart' structure of living matter" (2013, p. 57). In Meeting the Universe Halfway: Quantum Physics and the Entanglement of Matter and Meaning, Karen Barad argues that "[m]atter is produced and productive, generated and generative. Matter is agentive, not a fixed essence or property of things" (2007, p. 137). Hence, the mattering (using Barad's own concept) of embodiment in McBride's fiction relates to authorial, formative, agentive processes on the level of corporeality, perception and self-creation. In line with that, referring 
to Maurice Merleau-Ponty, Diana Coole maintains that "if it is corporeality that introduces meaning or structure into matter, this is because the body literally incarnates material capacities for agency" (2010, p. 101). Seen from that angle, embodiment in The Lesser Bohemians is "authored" and, at the same, it is "authoring" the agency of the female narrator. What is more, embodiment which, as stressed by N. Katherine Hayles, is never synonymous with the abstract body, constitutes its particular enactments, "excessive and deficient in its infinite variations, particularities, and abnormalities" (1999, p. 197). Since the formations of embodiment at all times are inseparably intertwined with the conceptions of the body (Hayles, 1999, p. 197), such repeated interactions are performative in their nature.

In McBride's second novel, performativity becomes literally underscored since both protagonists are personally and professionally embedded in their acting roles: Eily (18), the narrator, is an Irish student of a drama school in London - and Stephen (38), an English actor (of Irish descent), has years of practice on stage and on screen, with varying degrees of success. The plot of The Lesser Bohemians evolves in-between auditions and play rehearsals. However, the performativity of this fiction goes far beyond the level of the background or even language. As rightly observed by Barad, "performativity is properly understood as a contestation of the unexamined habits of mind that grant language and other forms of representation more power in determining our ontologies than they deserve" (2007, p. 133). Barad explains that performativity requires reflecting upon what is being observed but, above all, acknowledging, in a participatory way, one's own involvement in such practices:

A performative understanding of discursive practices challenges the representationalist belief in the power of words to represent preexisting things. Unlike representationalism, which positions us above or outside the world we allegedly merely reflect on, a performative account insists on understanding thinking, observing, and theorizing as practices of engagement with, and as part of, the world in which we have our being. (2007, p. 133)

The performative dimension of The Lesser Bohemians did not go critically unnoticed. Ruth Gilligan observes: "Discussions of learning certain roles and developing scripts, of embodying certain characters and motivations, all invite deeper considerations on the performative nature of the self (and, indeed of love)" (2017). With regard to the representationalist, plot-centred analyses, McBride's text (2016) may seem to be a conventional tale of sexual initiation/exploitation with a more or less stable gender dynamics. This could explain why what the author does with embodiment in her second novel has been assessed discordantly by critics. For instance, Lara Feigel (2016) in The Guardian praises The Lesser Bohemians for the "blending of speech and thought," the fact that "we don't see Eily's body, but we feel it from within," and appreciates a smooth transition between carnality and spirituality. Furthermore, Feigel claims that "within a single encounter, we can go from being just bodies, doing odd things to each other, to minds, urgently expressing love, without it being easy to define what has shifted." Feigel's interpretation, nonetheless, appears to reinstate McBride's novel within the mind/body dichotomy. In contrast to such an approach, viewed as a narrative experiment beyond the old-style binarism, the text can be said to free the female subject of a dual passive/active sexual roles framework. To achieve her aim, McBride uses what Johanna Thomas-Corr defines as "stream of preconsciousness," an acting method which, as the critic explains, involves "breaking down a character's experiences of the body and the mind and then finding 
a language that expresses them simultaneously" (2016). Regarding the novelist's writing technique, Gilligan aptly quotes McBride's own terminology about the "stream of subconsciousness [...] the moment just before language becomes formatted thought" (2017). What is more, materialism allows one to convey this simultaneousness: the materiality of both corporeal and mental processes disrupts the artificial post-Cartesian split. Following Melissa Orlie's reading of Nietzsche, one can state that any form of "mental activity [...] arises [...] from material elements that compose the physical body" (2010, p. 121) and, then, binarism can be avoided.

While a traditional stream of consciousness technique was informed by psychological and cerebral-neural discoveries, The Lesser Bohemians seems to draw upon the idiom of up-todate science, especially biochemistry and physics. McBride's technique relies heavily on the formal experiments with longer utterances, pauses, original punctuation (capital letters, missing full stops, etc.), word repetitions, dissimilar font sizes used in one passage, unconventional syntax and "cracked" word order. These intentional grammatical "mistakes" render the defiance of "the transformation of embodied experience, noisy with error, into the clean abstractions of mathematical pattern" (Hayles, 1999, p. 98). The Lesser Bohemians seems to defy the rules of grammar on purpose, as a statement; the book appears to challenge the "belief that grammatical categories reflect the underlying structure of the world," laying it bare as "a continuing seductive habit of mind worth questioning" (Barad, 2007, p. 133). Jeanette Winterson calls The Lesser Bohemians "a linguistic inoculation [...] Against text as data. Against language as information" (2016). The innovative use of language deconstructs the previous century's patriarchal patterns by the means of the narrator's material embodiment, the overtly sexual imagery and ungrammatical syntax. In The Lesser Bohemians, the sexual interactions in a coming-of-age framework mimic the Pygmalion myth in a subversive, performative way. However, regardless of unquestionable structural innovations, there could still be heard critical voices that insist on the novel's thematic traditionalism. John O'Sullivan, not without sarcasm, calls The Lesser Bohemians "a good old-fashioned love story" where "the self-destructive tortured male is rescued by the love of an occasionally good woman" (2016). Thomas-Corr goes even further than that, evoking "Jane Eyre crossed with the less murdery bits from Last Tango in Paris" (2016). The article challenges such critical opinions. It will be argued here that rather than reinstating a revitalised romantic convention, the novel subverts the cliché of the youthful female sensuality constituted by (aged) male bodies. The Lesser Bohemians depicts the narrator as engaged actively in the practice of corporeal sexual try-outs, exploring her own material boundaries and being in control of her embodiment. Claire Colebrook's comment on Michel Foucault's The History of Sexuality sheds light on Eily's practices: "sex becomes the truth of our being, and that which we must liberate in order to be whom we are," and she continues, arguing that "[s]exuality is $[\ldots]$ one way in which the self organizes its own relations with regard to what is not itself" $(2008$, p. 66).

Such organising becomes problematic as the defenceless sensuality of Irish women that McBride describes in her fiction tends to be marked by violence, rape and psychological devastation. In The Lesser Bohemians, hurt is transcended by performatively exploring sexual boundaries, thanks to which the main character overcomes her powerlessness. Gerry Smyth in his essay (2019) "Displacing the Nation: Performance, Style and Sex in Eimear McBride's The Lesser Bohemians," in the spirit of this article, writes about "the redemptive power of sex," putting into doubt the treatment of The Lesser Bohemians as "just another Irish 'trauma' 
narrative" (p. 161). What is more, analysing McBride's second novel in relation to what is defined as "traumaculture" (2019, p. 165), Smyth points to the major aspects that do not fit this particular concept. He claims that the main characters are located "beyond or after trauma" (p. 167), seeing in them not only "the figure[s] of an abused child," (p. 166) but also "recovering adult [s]" (p. 167) and states that "the process of healing may at least be broached" (p. 163).

Eily's sexual engagement with Stephen constitutes her first volitional experience of that kind, because earlier on, as a child in Ireland, she was for years a victim of sexual molestation and rape, "being at the mercy of someone with none" (McBride, 2016, p. 136). Smyth reads the motif of abuse in Irish fiction via the prism of the Catholic Church's scandals, postcolonial discourse and the patriarchal model of the so-called traditional family (2019, pp. 164-166). Androcentric and dysfunctional family is frequently depicted in $21^{\text {st }}$-century Irish literature as the site of silenced crimes against the most vulnerable ones (i.e. children), as claimed, for instance, in Kathleen Costello-Sullivan's (2018) Trauma and Recovery in the Twenty-FirstCentury Irish Novel. Such a correlation is not new, as observed by Nancy Whittier (2009), who traces it back to the 1970s, arguing that it was at that time that "feminists active against rape began targeting child sexual abuse as a political issue and one of the many forms of violence they argued affected women" (p. 21). In The Lesser Bohemians, one more aspect is underscored: the role of Irish mothers either as passive bystanders or perpetrators of abuse (Smyth, 2019, pp. 163, 165). The novel shatters the myth of Mother Ireland and idealised Irish motherhood. All too often such "enabling mothers" (Ricker, 2006) were raised in a misogynist milieu that taught them to be loyal to this system more than to their own children.

In The Lesser Bohemians, the bold experimentation with jouissance undermines the "imprint" of the woman's self-sacrificial love, shaped by the androcentric discourse and (the Irish) Catholic upbringing. All in all, despite being set in the 1990s and looking back retrospectively at the second wave of feminism, the novel's "apparatus" seems to be very much embedded in the twenty-first century and new patterns of female subjectivity. This is how Hayles (1999) accounts for their emergence: "They ... constitute the narrator, who exists less as a speaking voice endowed with a plausible psychology than as a series of fissures" (p. 45).

Aforementioned fissures in The Lesser Bohemians establish a mosaic of the specified situational framework and retrospections. The novel is set in London exactly between March 1994 and July 1995 with a few Irish homecoming scenes and reminiscences. The first person narrator refers to her country as "Wow Holy Catholic Ireland" (McBride, 2016, p. 71), adding that "in the cold and dark of Ireland, I burn my mouth away" (p. 73). When living in London, the speaker is judged along the line of stereotypical "Irishness," and the prolonged military conflict in the North, extended to the UK. In the times of recurrent bomb alerts during which people get evacuated in panic, the very act of reading an Irish newspaper on the tube may expose one to aggression. Eily notices: "never read the Irish Times. [...] the train gets held only five minutes like, and this fella starts going I know what this is, fucking bomb scare, fucking IRA" (p. 52). The speaker recalls insults of a co-passenger who verbally abused her as an Irishwoman: "he went apeshit, roaring Paddy bitch and your Paddy rag. We're all, stuck here 'cause of you lot" (p. 52). 
In her sexual initiation with Stephen, Eily enters a ground of consenting sensuality, the age differences, not to mention the divergence in their emotional baggage and social status. Eily needs to rely on the only thing that she assumes to "own" - her body. It turns out, however, that its agentic materiality astounds the speaking voice on numerous occasions. The narrator's imaginary concept of the body remains in perpetual discord with her corporeal sensations and her embodiment. It happens because

[e]mbodiment is akin to articulation in that it is inherently performative, subject to individual enactments, and therefore always to some extent improvisational. [...] embodiment becomes naturalised only secondarily through its interactions with concepts of the body. (Hayles, 1999, pp. 197-198)

To some extent, the performative and improvisational dimension of material corporeal enactments, as also observed by Smyth (2019, p. 173), could be compared with the rehearsals and auditions in which the narrator of The Lesser Bohemians participates. Eily is constantly making and re-making herself, and, therefore, the subject recurrently remains "forcibly" relocated to the end of the utterance. It does not occupy its key, frontal position, because it is yet about to take form. In a sentence not ended with a full stop, that meanders to the other paragraph, the narrator admits: "Fine my life'll be when it comes. When I am right. When I have made myself. When I have. When I" (McBride, 2016, p. 14). Like a non-accentuated syllable, "I" remains "reduced" and moved to a post-verb, weakened position. As stressed by Judith Butler in Gender Trouble, and resumed by Barad (2007), in a truly performative manner, it is the deed and not the doer that becomes centred. The speaker uses this reversed word order at the very beginning of the novel: "Working through its tunnels, now walking on its streets, a higher tide of people that have ever seen and - any minute now - In. Goes. Me" (McBride, 2016, p. 7). When the narrator admits: "I don't take for granted I," she means that she does not take "I" at face value, and she is aware that her subjectivity is in a process of becoming. Relying on homophonic likeness, she plays upon this idea in "Push me through to a different eye." Eily argues:

And my head turns drowse in its lazy rings at the starting pull of gravity. Push me through to a different eye, to this world of pearls polished up for I don't take for granted I. Not a single gasp of air. (McBride, 2016, pp. 10-11)

The same homophonic strategy is re-employed in "The congealing to form some other eye I can't focus into use" (McBride, 2016, p. 16). When an "eye" equals "I," the act of watching / being becomes challenged by "an iterated doing through which the subjects come into being" (Barad, 2007, p. 57; discussing Butler) that produces a self to a greater extent than word-order fronting. Barad (2007) reminds one that performativity is not about, as she calls it, "wording" the world but quite the opposite, about exploring the limits of language. She maintains that

performativity, properly construed, is not an invitation to turn everything (including material bodies) into words; on the contrary, performativity is precisely a contestation of the excessive power granted to language to determine what is real. (Barad, 2007, p. 133)

What is more, the body, unlike embodiment in-process, is regarded by Eily as a performative, theatrical costume in which she lies. The narrator in The Lesser Bohemians claims: "It's only from lying alone in this body too long, I should get someone to lie in it with me. I will. My 
will" (McBride, 2016, p. 16).The double meaning of lie as the horizontal bodily position and above all, the act of not telling truth indicates clearly that the speaker intends to dramatise her narrative instead of focusing on its veracity. Furthermore, the speaking voice resolves volitionally to extend her performance onto the other actor who will become her companion in the spectacle.

In The Lesser Bohemians, the speaker's embodiment becomes "the living matter" which, as Braidotti claims (2013, p. 60), is autopoetic and cerebral, but, at the same time, close to its organic derivations. The agentive matter reconnects the speaker with other material organic and non-organic forms. Furthermore, it is realised "between touching and being touched, activity and passivity, phenomenal and objective being" (Coole, 2010, p. 107). Following this line of thinking, performative embodiment is viewed as both "in" and "out," passive and active, perceived and perceiving. The following passage which commences with the clause of contrast illustrates it well: "But oh my body opts out and in. Flesh scraping fear against the Do of my brain. So slice my fingertips on every railing to keep by him up the Camden Road" (McBride, 2016, p. 6). The agency of the corporeal "living matter" is rendered by an active verb: "scrape," connoted with imprinting anxiety. It is juxtaposed with the emphasised (capitalised) grammatically incorrect (denominal and not gerundial) verb form: "the Do of my brain." "Do" is linked in one phrase with the material brain (not abstract mind), which is endowed with discerning activities. The pain-regulated discipline: "slice my fingertips" to "keep by him" shows that the narrator tries to subdue "the living matter's" resistance to execute movements. Elsewhere, Eily appears to effect her imperative constructions as directed against both the flesh's and the brain's in-actions. However, what the speaker wrongly defines as the indolence of her passive living matter (either in its cerebral or somatic dimension) is, in fact, their active refusal to co-operate:

Off into it so. Time rushing through days. Crucify lazy flesh. Defy lazy brain. And the much and much of delight, of make. Turning the body. Converting the self into flecks of form and re-form. Into someone else. Her. Into her. Into someone else. This one. (McBride, 2016, p. 137)

When examining the passage in question, it seems appropriate to remind one how aptly Winterson (2016) captures the succinctness of McBride's sentences, comparing it to "the Twitterstyle brevity $[\ldots]$ with none of the Twitter-style banality."

In the fragment above, the narrator's self is split into atoms in the process related by her as "converting the self into flecks of form and re-form." As shown above, in this process, Eily experiences her corporeality as loose atoms. Barad comments on how our understanding of atoms has changed over the years - they are nowadays acknowledged to be experientially observable and even transferable (2007, p. 354). As noticed by Barad, atoms constitute quite a heterogeneous mesh of "subatomic particles - including electrons, quarks, positrons, antiquarks, neutrinos, pions, gluons, and photons" (2007, p. 354). Since these days atoms are no longer viewed as abstractions, their introduction into the text acquires a new, scientific dimension. In the past, such an analogy could amount to the lack of a stable, continuous bodily image. However, because of the contemporary perspective on matter as agentic and not passive, it, paradoxically, allows one to acknowledge that the mattering process is, as Barad (2007/2008) states, "intra-active." Barad explains that in the concept of "intra-action," "matter 
is substance in its intra-active becoming - not a thing, but a doing, a congealing of agency. Matter is a stabilizing and destabilizing process of interactive intra-activity" (2008, p. 139). As shown above, the speaker's self is fragmented into tiny particles of matter. On the surface, the narrator in The Lesser Bohemians celebrates the materiality of her agentic autopoiesis. Citing Humberto Maturana, Hayles relates to autopoiesis as "self-making," “a living system's organization" working interactively via the circularity of progressions (1999, p. 136). Accordingly, Hayles reminds one that Maturana defines "the living organization" and its circular nature by describing its aim as safeguarding the making and the upkeep of constituents that identify it to the extent that the outcome of their operations equals the systemic structure that generates them in the first place (1999, p. 138).

Similarly, the syntactical constructions in The Lesser Bohemians are caught in their self-generating circularity, frequent reiterations, incompleteness and self-formation. The aforementioned "conversion" process, in conjunction with breaking the corporeal "living matter," subverts the rules of syntax: the subject is missing, sentence equivalents prevail, ungrammatical constructions multiply (i.e. "of make"). Since autopoiesis in its strong version seems to be self-contained, solipsistic and self-referential, Donna Haraway proposes to employ a broader term, sympoiesis, "making-with" (2016, p. 58). She elaborates this concept, adding: "[n]othing makes itself, nothing is really autopoietic or self-organizing. [...] It is a word for worlding-with, in company. Sympoiesis enfolds autopoiesis and generatively unfurls and extends it" (Haraway, 2016, p. 58). Even though she distances herself from the "self-sufficient 'self-making," Haraway would see both these terms as being in "generative friction, or generative unfolding" and not simply in conflict (2016, p. 61).

In The Lesser Bohemians, Eily's process of becoming embodied goes along the lines of "making-with" other material bodies; sympoiesis appears to render this mechanism much more accurately:

All bodies, not merely "human" bodies, come to matter through the world's iterative intraactivity - its performativity. This is true not only of the surface or contours of the body but also of the body in the fullness of its physicality, including the very "atoms" of its being. (Barad, 2007, pp. 152-153)

Similarly, the narrator feels correlated "to the thousands of cells of the thousands of bodies," and those are not just human bodies, as she mentions the atoms of water and the concrete wall. Such a vision of the cell imagery seems to be consistent with what Braidotti calls a "shift toward a biocentric perspective" where "the matter of the body and the specific materiality of bodies" have become focalised (2010, p. 201). Eily observes:

But in the froze water and distress turn myself to wall, to the thousands of cells of the thousands of bodies who have cleaned themselves off by these cracks. And I'd be one. Any of which, any, to slip this being this. Back scratched by some two. (McBride, 2016, p. 108)

In The Lesser Bohemians, the speaker's material embodiment may be dissolved in water and supported by the solidity of the brick. However, in materialist theory, these boundaries are mostly arbitrary: they signify "material (re)configurations of the world through which the determination of boundaries, properties, and meanings is differentially enacted" (Barad, 2007, 
p. 151). Drawing upon Richard Feynman, Barad (2007, p. 156) argues that the acceptance of bodily boundaries is psychologically constituted, being more a play of the diffraction of light and colour rather a physical borderline. In other words, "seeing is an achievement that results from specific bodily engagements with the world" (Barad, 2007, p. 156). In McBride's novel, the diffractions of embodiment ("slip this being this") constitute outlets through which these interconnected (re)configurations can be realised: "And so I wriggle in. Slip in. Remember people are blind to under your skin or. Under my skin now" (McBride, 2016, p. 9). The "sympoietic" syntax constitutes the making and re-making of the speaker's embodiment. The narrator in The Lesser Bohemians observes: "First particles only - split seams into its side making gateways into bodies that are not mine. The gyring off to anarchic sublime. The congealing to form some other eye I can't focus into use" (McBride, 2016, p. 16). The passage "the gyring off to anarchic sublime" seems to refer to W.B. Yeats's "The Second Coming" and William Blake's "The Tyger" ("The congealing to form some other eye"). Both these intertextual relocations draw upon the process of creation based upon the historiosophic dialectic of opposing but complementary forces. These contrasting elements are, thus, seen as interdependent and interconnected.

The "gyring" type of writing seems to be well-rendered in the scene when the inebriated narrator's embodiment remains in sync with the syntax which imitates the circular, pulsating rhythm of marry-go-round intoxication: "Skitter I little and traitor knees. And knees. Touched. Knees. And kissed at more" (McBride, 2016, p. 12). As demonstrated earlier, the verb of action is appositionally fronted before the subject, which disrupts the conventional word order. Once again, the text emphatically draws attention to the doing rather than the doer. The gravity of the "living matter" is qualified by the light "skitter." Paradoxically, against its lexical denotation, the subject cannot run rapidly or weightlessly. Her will seems to be inclined towards it, but the actions do not follow. That is why she accuses her body of betraying her (see "traitor knees"). Finally, the speaker's protesting subjectivity becomes vocalised. The non-cooperativeness of the living matter reawakens the conscious intervention: "I am I think I better go" (McBride, 2016, p. 12). By saying "no" or "stop," the narrator learns the boundaries of her self, while the boundaries of the living matter become fluid. In this case, there is a unity of the materiality of a person and motion. In The Lesser Bohemians, her atomic embodiment surfaces mostly in the figurative boundary-crossing scenes when the speaker puts herself in danger due to excessive substance abuse or sexual interactions with strangers. Elsewhere, the narrator talks of herself as:

bits of body, floating parts, there for a finger in the mouth or What? You know what things. In the atom though his fancying must be a lie and I go so far from my body now. Left, from his skin to the switching off. Turn it down. Turn it Stop! I Stop Please Stop. And both my arms across until the air goes lock. (McBride, 2016, p. 48)

What draws immediate attention in the cited passage is the graphic transcription of smaller and larger fonts. The protagonist compares her embodiment to a malfunctioning, broken down mechanism which she wishes to deactivate, switching off her "floating parts." The floating syntax matches the fragmentation of the unattached bodily matter ("bits of body, floating parts, there for a finger in the mouth or What?"). Each of them seems to act on their own and be only loosely connected, if at all, with other parts. The narrator in The Lesser Bohemians expresses 
her death-wish fantasy to become an unfastened amalgamation of particles ("you're dying to be a looser-limbed doll") but this wish is tentatively rendered in the second person ("you'll diffuse"), as if addressed to somebody else. Because her corporeal particles become dispersed, she comes close to merging with the world's materiality (Frost, 2010, p. 160). Again, material forces of "mortification, re-attuning" seem to organise her formative process:

And anyway you're dying to be a looser-limbed doll. Wrong at the first post. Ah there'll be again, claims mortification, re-attuning itself. Before long you'll diffuse in the city's fuzz and after all, I recall, footing traces of chips, tomorrow is another day. (McBride, 2016, pp. 12-13)

In most of the scenes in The Lesser Bohemians, the observation is conducted as if from above: the narrator watches her body being acted upon, which requires "inter-involvement between embodiment, movement, body image, touch, sight, smell, language, affect, and color" (Connolly, 2010, pp. 184-185). In other words, Eily scrutinises herself through the eyes of her lover, becoming "an observing system observing itself observing," as Hayles defines the process, analysing Maturana's theory (1999, p. 144). The narrator admits: "I understand better now, amid this journey into what I am. Just the body of a woman looked at by the body of a man. And I catch the eyes. And I go over there" (McBride, 2016, p. 252). Hence, Eily watches herself being watched by the Other. Her agency is reduced to the projections of what the observer being observed might think: "he wants," "it is for him." "His beautiful eyes on me and his beautiful body pacing inside" nearly obliterate the negated beginning: "Not where I allow." The absence of her subjectness is spotted and addressed: "asking Are you with me? I am." The narrator confirms: "I. He I am" (McBride, 2016, p. 125). Barad assumes that "[p]erformativity is linked not only to the formation of the subject but also to the production of the matter of bodies, as Butler's account of 'materialization' and Haraway's notion of 'materialized refiguration' suggest" (2008, p. 126). The performativity constitutes the mattering of Eily's textual body. The account of the speaker's presence is followed by sense-perception: "All my body, lighting, all over his. I could say anything, anything. Just feeling and heat as and. Wet from inside him so far up inside me" (McBride, 2016, p. 125). Barad stresses that agency, in a posthumanist understanding, has nothing to do with people's conscious will; it is not their exclusive property or a claimed state; it is not synonymous with acting, possessing or existing (Barad, 2007, pp. 177-178). She concludes that "[a]gency is not an attribute but the ongoing reconfigurations of the world" (Barad, 2008, p. 135). These configurations allow Eily to enter interactions with other bodies, which blurs the edges of her own corporal distinctness:

Building up until she didn't know how to not. Then she'd let herself and tell herself it was alright because he was just a part of her really, another part of her own body. He belonged to her, after all. (McBride, 2016, p. 287)

The speaker in The Lesser Bohemians appears liquefied in the narration to the point of nearly turning into loose atoms. It becomes clear that the formative process seems to be controlled by some external cogency rather than by "her." The skin boundary becomes fluid and shared by more than one person: "No, no more, I say for we are in such fragile skin, so close to getting lost in the in-between" (McBride, 2016, p. 216). The element of the persona's responsiveness to the needs of her lover acquires a particle-like dimension of "stretching": "Then he kisses me until I'm grand. Until I'm airy in fact. Can be. Full of sex and dare. Stretching and 
letting him do the mop up himself" (p. 87), "Just open myself to his body in mine. Stretching to the want of him all over me now. This is it and I am like normal like" (p. 68).

As seen, the body of McBride's novel (2016) is stretched beyond normal due to redundant spaces. The extra spaces in the text render the hesitation-like pauses, when the narrator does not feel at ease, and the qualifier "like" implies that clearly. The totality of the bodily experience is not allowed to the subject in the moment when she is wholly stretched "for" somebody else, when she is not entirely in her "living matter." That is why the process begins with negation: "Not where I allow every journey he wants to make across my body" (McBride, 2016, p. 125). The speaker employs the particle metaphor to contrast the unified self of the male protagonist ["To where I live. I live there and know that now. Every bit of you lives here. No bit of you lives anywhere else" (McBride, 2016, p. 97)] with her own bits that are emitted purposefully but according to the mould that is not her own: "So I lie down to become bits of girl for him and one who's going to have it bad" (p. 94). The bits of the speaker in order to function as the whole need a clear support of the system: "a cell within my body may be considered as a system in itself, but it relies for its continued existence on its structural coupling to my body as a whole" (Hayles, 1999, p. 138).

When the narrator asserts: "they'll kick you to bricks then desert you to rebuild," her reconstruction seems as violent as in John Donne's Holy Sonnet 14, "Batter My Heart Three-Person'd God." It ends with the broken-English "praise" of her alleged docility: "Very like and nice verl." The speaker records:

Float up of stories. Legs go serene. [...] they'll kick you to bricks then desert you to rebuild. Deconstruct you, they say It's no lie. My brain puckers with these, then - surprise - divides and the room begins to spin. Very like and nice verl. (McBride, 2016, p. 12)

To some extent, the main character treats her embodiment in a similar way to a performative artist, Marina Abramović. Her MoMa performance The Artist is Present (2010) involves a basic setting: a table with two chairs facing each other. One was occupied by the performer (Abramović), the other one, vis-à-vis, was empty and could be taken by anybody from the audience. The behaviour of the accidental participants was not constrained, and, in the course of time, it escalated into aggressive acts. Like Abramović in The Artist is Present, Eily tends to push her embodiment into contexts that could be knowingly abusive and manipulative. Due to interactions with other sexual/sexed bodies, the narrator acquires data how her sensuality re-assembles itself though and within her own materiality. Eily exposes her body's materiality to contacts with the outer world to mark the boundaries of her own self. Sex becomes the experimental ground in which her bodily materiality becomes tested. Asking the rhetorical question on, "And how much do I already know I can take," what the narrator in The Lesser Bohemians really wishes to know is with what she would be willing to put up. Her body becomes a vacant chair open to others. She chooses to pass her "living matter" "to their want" to be used. Like Abramović, the speaker enters the contexts where her safety might be compromised, where she abandons self-control ("I open my things saying Lads, do anything"). Eily comments: 
And how much do I already know I can take. To spite myself, for him. To hurt myself. I open my things saying Lads, do anything. Nothing matters. And it is nothing. Empty vessels making most sound. Stretch her. She deserves it. The well-trained mouth. Just go where she treads herself underfoot. Beneath unwashed bodies. She chooses this. This time she chooses what she is. Beyond the fright, even disgust, she passes her body on to their want and only when they have fucked enough goes down to the sleep where no dream penetrates. (McBride, 2016, p. 106)

Once again in The Lesser Bohemians the imagery of stretching resurfaces; the narrator stretches her resilience, well-being and even safety. Stretching becomes a form of self-inflicted punishment that she assumes to deserve. That is why Eily seeks sexual interactions that put her life in danger. Her dysfunctional and self-harming "choice" ("To spite myself, for him. To hurt myself.") is made as an offering to Stephen. For him, she wishes to stretch her body beyond any boundaries, beyond revulsion and distaste, "Beyond the fright, even disgust," "Beneath unwashed bodies," towards the sensations of abject. Referring to McBride's first novel, Smyth makes an observation which, to some extent, can be applied to The Lesser Bohemians as well:

Because of the physical abuse to which narrator was subjected at such a young age ... her own body becomes the preferred site of that occupation; the pattern of loveless sexual activity in the present derives from the violence of that first invasion, while the mortification of her own body distracts the narrator from having to return to the place of pain. (2019, p. 172)

When being intimate with Stephen, Eily engages in similar self-debasing performativity. Paradoxically, when she announces: "You can do anything you want to me," "Hit me, I want you to hit me or fuck me till I bleed," (McBride, 2016, p.112) her lover shockingly faces the validity of that statement. By abandoning control, Eily forces Stephen to assume responsibility for his actions towards her. This performative way makes Stephen confront the fact how abusive his actions might be towards her body and self. Since Eily refuses to control the narrative, the "other participant" will have to own up to the consequences of his actions. Stephen seems to realise that when he urges her to discontinue: "he's shaking me Stop saying those things." Eily argues:

But what worthless limbs can't, my mouth invites Hit me, I want you to hit me or fuck me till I bleed. You can do anything you want to me, until he's shaking me Stop saying those things, like I'm only half wild when I really, all am, Would he hate me? (McBride, 2016, p. 112)

At first, pain becomes associated with sexuality because when experienced through her virginal body, penetration causes Eily physical discomfort. It feels as if her "living matter" was torn apart. Her entire body seems cracked: "a pain running wild from his body far into mine. I bite my own lip and stare above. Ceiling swerves there. Cracks. Worlds beyond pain not improving. Now. Or now. Or yet. I wish I hadn't. I'd never done this”' (McBride, 2016, p. 32). On the other hand, even emotional closeness might induce hurt. What the narrator describes as torture is the sensation of holding hands: 
There is so much love. The eyelids flutter up and he smiles before remembering. Then just looks at me. Somewhere below though he finds my hand. Works his fingers in through mine. But the hurt is so fine I must torture it for more. (McBride, 2016, p. 39)

Experiencing sensuality materialises on the level of embodiment; this is where individual perceptions are realised, these pleasurable and the painful. Drawing upon Nietzsche, Orlie explains that these two sensations evoke vulnerability and activate the thinking process because they lie beyond the control of the subject who "creates itself" by wishing either to repeat them or refrain from them:

The ego that says "I think" emerges in response to experiences of either pain or pleasure because both are always to some degree beyond its control. The "mind" is the means by which the body imagines itself as master of the conditions of its experience but at exactly those moments when the body actually feels the limits of its strength and suffers under these conditions. This experience of vulnerability and the emergence of "mind" as a response to suffering to which it attests is the very process of the body despairing at and of itself. (2010, p. 123)

The sexed female body is "the living organization" and, at the same time, it undergoes various "inscribing practices." When pleasure and pain involve incorporation, shame seems to be inscribed into Eily's body. Hayles relates "inscribing practices" to the body whereas embodiment is identified with "incorporation" (1999, pp. 193, 199-207). As shown, a similar distinction seems to be acknowledged by the speaker in The Lesser Bohemians. The following fragment focuses on the body being acted upon:

His tongue finding feeling I cannot avoid where I am. Late restraint ebbing. [...] Shame biting my lip down to blood and all the pleasure rushing through. [...] I cover my face. Sift through surprise for the way my blood beats. Fragile in the wither. [...] It was it was good - trying to arrange back into a body that only wants his close. (McBride, 2016, p. 67)

The mortification of the sexually active female body is imprinted upon the narrator's corporeality ("leaving me in a body") - whereas while in her atomic "living matter" state, the speaker does not seem to be confined by it. Her embodiment extends beyond the constructed body's self-consciousness. The corporeal matter bursts, moves, feels and produces sound:

And far beyond shame my body longs. And him doing all he can to drag it down. So I hide against him. In his neck. Let it go through. Like a burst. Like a hurt. [...] Leaving me in a body clicking inside like it never has. (McBride, 2016, p. 69)

Hayles discusses a crucial interaction between the body as a site of received inscriptions and embodiment as ways in which subjects, on their own, express and relate to them (1999, p. 193). Similarly, Tobin Siebers stresses that sex belongs to the public domain as it is embedded in the social debate concerning bodily normativity (2008, p. 296). The narrator in The Lesser Bohemians experiences her embodiment during sex when she "leaves her body," when social and cultural inscriptions are switched off (she is "trying to arrange back into a body"). "Being bent like a body" indicates that she is detached from "inscribing practices" when she is "incorporated." Extra spaces render the fluctuations in the breathing pattern. Eily comments: 
Fresh inclination and the blood goes up Bends me like a body puts inside into my mouth and we deep and open where is no mistake, where are only runs of thought of next of kissing him in that short past, naked and He stops I stumble forward to in perfect dazed unfurl his breath on my hot cheek then kissing me further. (McBride, 2016, p. 43)

When incorporated, the speaker experiences "the absence of her body," her atoms mingle with the scent-particles of others: "Dancing in the absence of my body. Weight or look or pain. As though I am perfection moving against the sweat of strange men" (p. 100). Perfection permeates disgust (sweat and reek).

Along with self-debasing practices in The Lesser Bohemians, one more form of embodiment needs to be taken into account: the Oedipal body. As argued before, early twentieth-century psychology has been overshadowed in McBride's fiction by the imagery derived from twentyfirst-century science, mostly physics. In The Lesser Bohemians, the pseudo-psychoanalytical subplot embodied by Stephen's troubled relation with his daughter of Eily's age can be regarded as the weakest part of the novel. In this oversimplified construing, both characters seem to replace the true objects of their longing: an absent child and a not present parent. Eily observes:

This is my father. Taking my knickers down. Putting his fingers. Putting his mouth. This is my father. The want he makes and I have no father. Who cares? Who cares? [...] God that's so lovely, you are so wet. He is my father. I prefer him this to that. My father. I choose your father over the dead. Choose to kiss and touch and fuck so it hurts. And good to be hurt by him in ways you never will. (McBride, 2016, p. 125)

Eily's superiority, emerging in an imaginary dialogue with Stephen's daughter, Grace ("your father"), becomes realised in her professed ability to suffer ("And good to be hurt by him in ways you never will"). Being an Oedipal body in a sexual relation inaccessible to Stephen's biological offspring remains Eily's personal triumph but also a source of her anxiety. Stephen feels disturbingly unsettled in his father-figure role and, by transference, he punishes Eily for Grace's rejection. Despite Eily's declarations that she accepts performatively her "daughtercharacter," she has to repeat her line several times to make it sound convincing. Her distress is articulated in recurrent, obsessive rhetorical questions: "Who cares? Who cares?". Moreover, Eily asserts her subjectivity repeatedly by stressing the autonomy of her actions: "I prefer him that," "I choose your father," "Choose to kiss." However, words, even when reiterated several times, do not become truer. All in all, Stephen's unresolved personal fixations force Eily into a role that she feels uncomfortable playing. Positioned into "a character" from a different tragedy, Eily struggles to surface in her own discourse. What is more, Stephen's protracted speech intercepted into the text interrupts the forming of the narrator's embodiment. The reviewer from The Independent defines Stephen's oration as "a combination of melodrama and platitudes that makes him sound like he's auditioning for a part in a soap opera" (Liu, 2016). Gilligan seems to be equally displeased with Stephen's soliloquy, calling it "70 pages of pure, harrowing exposition [...] devoid of any experimentation whatsoever" (2017). In conclusion, the novel functions well when it stays within its bodily-matter; when it strands into the second-rate psychology, instead of intended "depth," it lays bare its deficiency. 
The Lesser Bohemians' major strength comes from the fact that the book relies on experimental theory both in its form and structure. It does not only reinstate the materiality of the body and text, but it adheres to the active view of matter as agentive and constructive. It brings one to the conclusion that "primary semantic units are not 'words' but material- discursive practices" (Barad, 2008, p. 135). Winterson captures it aptly: "It has taken time - culturally, critically - and particularly for women, to put language back into the atom smasher, to play with the form, to dodge the weight of storytelling and be taken seriously. Things are changing" (2016).

\section{References}

Abramović, M. (2010). The artist is present [performance].

Barad, K. (2007). Meeting the universe halfway: Quantum physics and the entanglement of matter and meaning. Durham and London: Duke University Press.

Barad, K. (2008). Posthumanist performativity: Toward an understanding of how matter comes to matter. In S. Alaimo \& S. Hekman (Eds.), Material feminisms (pp. 12-54). Bloomington and Indianapolis: Indiana University Press.

Braidotti, R. (2010). The politics of 'Life itself' and new ways of dying. In D. Coole \& S. Frost (Eds.), New materialisms: Ontology, agency, and politics (pp. 201-218). Durham and London: Duke University Press.

Braidotti, R. (2013). The posthuman. Cambridge: Polity Press.

Colebrook, C. (2008). On not becoming man: The materialist politics of unactualized potential. In S. Alaimo \& S. Hekman (Eds.), Material feminisms (pp. 52-84). Bloomington and Indianapolis: Indiana University Press.

Connolly, E. W. (2010). Materialities of experience. In D. Coole \& S. Frost (Eds.), New materialisms: Ontology, agency, and politics (pp. 178-200). Durham and London: Duke University Press.

Coole, D. (2010). The inertia of matter and the generativity of flesh. In D. Coole \& S. Frost (Eds.), New materialisms: Ontology, agency, and politics (pp. 92-115). Durham and London: Duke University Press.

Costello-Sullivan, K. (2018). Trauma and recovery in the twenty-first-century Irish novel. Syracuse: Syracuse University Press.

Deleuze, G., \& Guattari, F. (1987). A thousand plateaus: Capitalism and schizophrenia (B. Masumi, Trans.). Minnesota: University of Minnesota Press.

Feigel, L. (2016, September 2). The Lesser Bohemians by Eimear McBride review - a brilliant evocation of sex and intimacy. The Guardian. https://www.theguardian.com/books/2016/sep/02/the-lesser-bohemians-by-eimear-mcbride-review.

Frost, S. (2010). Fear and the illusion of autonomy. In D. Coole \& S. Frost (Eds.), New materialisms: Ontology, agency, and politics (pp. 158-177). Durham and London: Duke University Press. 
Gilligan, R. (2017, January). Form, autobiography, sex: Eimear McBride's second novel. Los Angeles Review of Books. Retrieved October 10, 2018, from https://lareviewofbooks.org/article/form-autobiography-sex-eimear-mcbrides-second-novel/.

Hayles, N. K. (1999). How we became posthuman: Virtual bodies in cybernetics, literature, and informatics. Chicago and London: University of Chicago Press.

Haraway, J. D. (2016). Staying with the trouble: Making kin in the Chthulucene. Durham and London: Duke University Press.

Liu, M. (2016, September 1). The Lesser Bohemians, Eimear McBride, review: "as accessible as it is startling." The Independent. https://www.independent.co.uk/arts-entertainment/books/reviews/the-lesser-bohemians-eimear-mcbride-review-as-accessible-as-it-is-startlinga7219576.html.

Merleau-Ponty, M. (2003). Nature: Course notes from the Collège de France. Compiled and with notes by D. Sèglard (R. Vallier, Trans.). Evanston: Northwestern University Press.

McBride, E. (2016). The Lesser Bohemians. London: Faber and Faber.

Orlie, A. M. (2010). Impersonal matter. In D. Coole \& S. Frost (Eds.), New materialisms: Ontology, agency, and politics (pp. 116-136). Durham and London: Duke University Press.

O’Sullivan, J. P. (2016, October 29). Eimear McBride's book The Lesser Bohemians is a sexual awakening. The Irish Examiner. https://www.irishexaminer.com/ireland/eimear-mcbridesbook-the-lesser-bohemians-is-a-sexual-awakening-428148.html.

Ricker, A. (2006). The ultimate betrayal: The enabling mother, incest and sexual abuse. Tucson: See Sharp Press.

Siebers, T. (2008). Disability experience on trial. In S. Alaimo \& S. Hekman (Eds.), Material feminisms (pp. 291-307). Bloomington and Indianapolis: Indiana University Press.

Smyth, G. (2019). Displacing the nation: Performance, style and sex in Eimear McBride's The Lesser Bohemians. Studi irlandesi. A Journal of Irish Studies, 9, 161-178. DOI: http://dx.doi.org/10.13128/SIJIS-2239-3978-25510

Thomas-Corr, J. (2016, October 10). Two desperately damaged people learning to love each other. The Evening Standard. https://www.standard.co.uk/lifestyle/books/the-lesser-bohemians-byeimear-mcbride-review-a3340456.html.

Whittier, N. (2009). The politics of child sexual abuse: Emotion, social movements, and the state. Oxford: Oxford University Press.

Winterson, J. (2016, October 12). A new Irish novel features few commas and lots of sex. The New York Times. https://www.nytimes.com/2016/10/23/books/review/eimear-mcbride-lesser-bohemians.html.

Dr hab. Katarzyna Ostalska (née Poloczek) is employed as Assistant Professor in the Department of British Literature and Culture at the University of Lodz, Poland. In 2015, she published a book Towards Female Empowerment-The New Generation of Irish Women Poets: Vona Groarke, Sinéad Morrissey, Caitríona O’Reilly, and Mary O'Donoghue. She co- 
edited two collections of essays on Irish Literature and culture. The new volume of articles, co-edited with dr Tomasz Fisiak, The Postworld In-Between Utopian and Dystopia: Intersectional, Feminist and Non-Binary Approaches in $21^{\text {st }}$-Century Speculative Literature and Culture, published by Routledge, is coming out at the end of 2021. She is the Head of the Posthumanities Research Centre at the Faculty of Philology, University of Lodz. 